\title{
Modernization Issues of Staffing the Penal Enforcement System in the Context of Formation of an Administrative Constitutionalism Doctrine in Modern Russia
}

\author{
ROMAN V. NAGORNYKH \\ Vologda Institute of Law and Economics of the Federal Penitentiary Service of \\ Russia, Vologda, Russian Federation \\ ORCID: https://orcid.org/0000-0002-4765-8550, e-mail: nagornikh-vipe@mail.ru
}

YANA V. VASIL'EVA

North-Western Institute (branch) of the Moscow State Law Academy named after Kutafin O.E., Vologda, Russian Federation

ORCID: https://orcid.org/0000-0001-9434-7563, e-mail: yana.vasileva@list.ru

\section{NATALIYA A. MEL'NIKOVA}

Vologda Institute of Law and Economics of the Federal Penitentiary Service of Russia, Vologda, Russian Federation

ORCID: https://orcid.org/0000-0002-3697-4769, e-mail: melnatale@mail.ru

\begin{abstract}
Introduction: today the state policy in the sphere of public service and PES staffing is focused on providing penitentiary institutions with competent and skilled specialists capable of performing state tasks in the field of execution of criminal penalties in difficult conditions. The processes of formation and development of the staffing system, meeting modern needs of the state and society development, are due to a variety of political, social, economic, legal and organizational factors that have both external and internal effects on its functioning. Neutralization of negative factors is possible only by increasing the efficiency of management activities in the PES as a whole and staffing in particular. The purpose of this article is to identify key directions for elaboration of administrative legislation in the field of public service and staffing the penal enforcement system in the framework of a new stage of constitutional transformations in modern Russia. The methodological basis of the work is formed by general scientific and private scientific (logical-legal, comparative-legal, descriptive, content analysis) methods of cognition of legal reality. Conclusions: the proposed directions for the formation of a theoretical doctrine of public service and PES staffing on the basis of integrative legal understanding of processes and phenomena of social development, improvement of administrative legislation on public service in the PES through its further constitutionalization, development of personnel policy through the adoption of the Concept for personnel policy in the penal enforcement system will lead to a systematic change in the mechanism of staffing the penal enforcement system, strengthening its resistance to countering threats of a criminal nature, and enhance performance of penitentiary institutions in general. The scientific and practical significance of the work consists in substantiating practical proposals for improving current administrative legislation in the field of public service and PES activities.

$\mathrm{Ke}$ y w o r d s : public service, staffing, administrative and legal regulation, constitutional principles.
\end{abstract}

12.00.14. - Administrative law; administrative process.

F o r c it a t i o n: Nagornykh R.V., Vasil'eva Y.V., Mel'nikova N.A. Modernization issues of staffing the penal enforcement system in the context of formation of an administrative constitutionalism doctrine in modern Russia. Penitentiary Science, 2021, vol. 15, no. 4(56), pp. 896-903. DOI 10.46741/2686-9764-2021-15-4-896-903. 


\section{ing}

State of the penal enforcement system staff-

Staffing the penal enforcement system of the Russian Federation (hereinafter referred to as PES) is designed to focused on providing penitentiary institutions with competent and skilled specialists capable of performing state tasks in the field of execution of criminal penalties in difficult conditions. The processes of formation and development of the personnel support system, adequate to modern needs of the state and society development, are due to a variety of political, social, economic, legal and organizational factors that have both external and internal effects on its functioning.

Staffing the penitentiary system in our country, despite a long period of attempts to bring it into a qualitatively new state, is still far from perfection and constitutional ideals of a legal democratic state.

According to the Portal of Legal Statistics, the persistent high crime rate in Russia [2] has an extremely negative impact on the state of crime within the penitentiary system itself, including among its employees. Currently, the involvement of PES employees in criminal relations remains quite high [4, p. 20]. In 2020, 99 criminal cases were initiated against $56 \mathrm{em}-$ ployees of the penal enforcement system, 170 employees were dismissed from the penal enforcement system for committing official misconduct [17].

Some crimes have an increased public response, which causes alarm in society, negatively affects authority of the penal enforcement system and prestige of public service [9, p. 346,$347 ; 6$, p. 72]. Besides, an extremely low level of social protection of employees, especially junior officers and enlisted personnel causes a significant shortage of this category of employees. As of January 1, 2021, $10.6 \%$ of the positions remained vacant in the PES, while the shortage of junior officers and enlisted personnel amounted to $12.5 \%$ [5].

Staffing the penal system has been regularly negatively influenced by factors of inefficient public administration, poor management and voluntarism during the PES administrative reform in 2009-2011, absence of any serious scientifically based models for its modernization at the beginning of the reform, etc.

Nowadays there are still many problems in the field of public administration of the penal system. Despite the adoption of a number of important strategic documents in the sphere under consideration, such as the Federal target program concept "Development of the penal enforcement system (2017-2025)" and the Concept for the development of the penal enforcement system of the Russian Federation for the period up to 2030, the staffing level and its state are still negatively affected by:

a lack of a modern scientifically based doctrine in this area, which leads to significant distortions in the development of legislation and practical personnel work in the penal enforcement system;

significant shortcomings in the legislation on public service in the penal enforcement system due to permanent borrowing of key provisions of the legislation on service in the internal affairs bodies;

absence of a single conceptual document (the Concept for personnel policy in the penal system) adopted at the level of the Federal Penitentiary Service of Russia and defining the main goals, objectives, principles and directions for improving staffing of the penitentiary system.

Doctrine of public service and staffing the penal enforcement system

Comprehensive modernization of the penal system, bringing it in line with the requirements of the updated Constitution of the Russian Federation (hereinafter - RF Constitution), fundamental international legal acts in the field of protection of human rights and freedoms, international standards of penitentiary activity is the most important state task and requires a deep revision of the current model of staffing penitentiary institutions, based on the elaboration of a new theoretical doctrine in this area.

Elaboration of scientific doctrine should be based on fundamental works of domestic and foreign scientists - representatives of various branches of scientific knowledge, taking into account their critical understanding and adaptation to Russian realities [16]. At the same time, it is necessary to take a very balanced attitude to the evaluation of results of previously obtained scientific research and forms and methods of personnel work in the law enforcement sphere developed on their basis, tested by long-term practice and generally proven themselves positively, which is especially relevant in modern conditions of the development of penitentiary science and practice. 
Recently, opinions have been actively expressed regarding "expediency of rethinking previously obtained scientific results in the field of work with the PES personnel in connection with new economic, socio-political and legal (including international legal) realities" [1]. Such a statement of the issue certainly deserves attention, since new conditions for functioning of the penal enforcement system, the law enforcement system and the entire state objectively require new scientifically sound solutions in the field of staffing. However, reasonable questions arise: how outdated the previous scientific views and, accordingly, the practical forms and methods of working with law enforcement personnel in general and the PES in particular are, and what areas of scientific research in this regard should become a priority? It seems that the solution to the problems of improving staffing of the PES is of a multi-vector or multifunctional nature [19, p. 8] and should be accompanied by scientific research in many branches of scientific knowledge.

At the same time, negative phenomena in the PES practice require particular attention, first of all, of management sciences - the theory of public administration, administrative and penal enforcement law. These branches of scientific knowledge in relation to the study of the problems of organizational activity and legal regulation of the penal enforcement system are closely interrelated [10, p. 28; 20, p. 6-9]; they have many interdisciplinary connections, similar scientific tools and conceptual apparatus, a common subject of scientific analysis, which form managerial (organizational and legal) relations in the field of execution of criminal penalties. In this regard, staffing the penal enforcement as a supporting subsystem of penitentiary activities should be considered as a common subject of scientific analysis for managerial branches.

Elaboration of doctrinal provisions in the field of personnel management in the penal system should be considered as one of the most relevant areas of scientific support for penitentiary activities in the context of scientific analysis of other areas of law enforcement activities of the state as a whole. The paradigm of integrative understanding of law [8], as well as scientific ideas about boosting constitutional democracy and administrative constitutionalism in modern Russia should be a methodological basis for the new scientific doctrine of public administration in the field of staffing law and penal enforcement systems [18].

The essence of the integrative approach consists in rational unification of advanced ideas of natural law, legal positivism, historicalconservative understanding of law, psychological, sociological, as well as other non-classical types of it from the position of priority of social humanistic principles of legal regulation of public relations [12, p. 18].

In turn, the use of an integrative understanding of law when creating a new doctrine of public service in the penal system and its staffing should focus on achieving the goals of legal regulation and organization of practical activities from the standpoint of priority of social humanistic principles of penitentiary activity, high spiritual and moral foundations of service, patriotism and duty in the performance of official duties.

In general, integrative legal understanding of public service in the law enforcement sphere is based on the priority of fundamental rights, freedoms and interests of a person, not in an individual, but in a universal context, its security from threats of a criminal, natural and manmade nature. In this regard, the theoretical model of public service in the law enforcement sphere, based on integrative understanding of socio-legal processes and phenomena, assumes consideration of this type of public service as a professional activity focused on comprehensive protection of fundamental rights and freedoms of citizens, interests of society and the state from threats of a criminal, natural and man-made nature [13, p. 124]. Hence, public service in the PES should also be focused on protecting fundamental rights and freedoms of citizens, interests of society and the state from threats of a criminal nature through execution of criminal penalties and application of criminal law measures to persons who have violated the law.

Thus, the theoretical doctrine of public service and staffing penal institutions should be an integrative system of scientific principles, views and ideas about key phenomena and processes in the field of public-service relations in the penal system and their organizational and legal regulation, which is based on the highest legal values of humanistic attitude to a person, his rights and freedoms. At the same time, public service and staffing the penal enforcement system can be successfully carried out only on 
the basis of development of spiritual and moral principles of the service, comprehensive observance of fundamental human and civil rights and freedoms, promotion of responsibility to society and the state, patriotism, duty and conscientious service to the fatherland among PES employees.

Constitutional reform and development of legislation on the service in the penal enforcement system

The tasks of improving legislation on PES activities have acquired particular relevance in the context of the constitutional reform carried out in our country, during which key vectors of further socialization of the state are identified, crucial strategic guidelines for modernization of the public administration system are outlined, prerequisites for further transformations in the field of democratization and humanization of public life are created. The RF Constitution necessitates further constitutionalization of existing branches of law, emergence of new human rights and freedoms and corresponding legal mechanisms for their implementation [7], which affects all spheres of public administration without exception, including the penitentiary system and its staffing.

Theoretical foundations of a modern concept of administrative constitutionalism [22, 25], which replaced the administrative state concept and became widespread in foreign legal systems [21, 24], reveal deep convergence (from the Latin convergo "bring together") of key constitutional provisions with the current legislation, particularly administrative legislation regulating relations in the field of public service and staffing law enforcement agencies.

Constitutionalization of administrative legislation is a process of establishing direct links between legislative acts in the field of public administration and constitutional values, such as equality, due process and the rule of law [23, pp. 515-516]. This process is characteristic of the vast majority of legal systems focused on strict observance of human rights and freedoms, and is a fundamental vector of constitutional development of our country for decades to come.

In this regard, deepening of constitutionalization of administrative legislation on public service in the law enforcement sphere will inevitably affect the subsystems of staffing law enforcement agencies, which will lead to a deeper penetration of constitutional ideas into departmental regulatory regulation of staffing. Unfortunately, the processes of constitutional expansion in these subsystems of administrative and legal regulation are currently virtually suspended, which objectively determines the need to change the political will and decisive actions on the part of the legislator. It is important to return to the idea of adopting a single law on law enforcement service (on a new constitutional basis), and as an intermediate step to enshrine basic constitutional principles, such as federalism (articles 4, 5, 15, 69, 71, 72, 73, 78 of the RF Constitution), legality (Article 15 of the RF Constitution), priority of human and civil rights and freedoms (Article 2 of the RF Constitution) in the laws on public service in individual law enforcement agencies.

Constitutionalization of administrative legislation on public service in the law enforcement sphere should imply harmonization of the entire array of regulatory legal acts on public service with the Constitution of the Russian Federation, including by consolidating current institutional principles of public service in the laws on its individual types, namely principles of unity of legal and organizational foundations of public service, openness of public service, stability of service, accessibility of information about service, interaction with public associations and citizens, security of employees.

Democratization of service in the penal enforcement system on the basis of the amended Constitution of the Russian Federation should also provide for introduction of the principles of public service known to domestic pre-revolutionary and modern foreign public law, such as publicity, priority of professionalism and personal service, prestige and special social status of employees, decent state monetary remuneration, correspondence of ranks and ranks of professional service of various types.

All these principles should be unconditionally reflected in the current Federal Law No. 197-FZ of July 19, 2018 "On service in the penal enforcement system of the Russian Federation and on amendments to the Law of the Russian Federation "On institutions and bodies executing criminal penalties in the form of deprivation of liberty", and in the future in the law on the state law enforcement service.

Attention should also be paid to the fact that at present the laws on sectoral varieties of public service in the law enforcement sphere 
contain only blank norms that service in these bodies is carried out in accordance with basic principles of the construction and functioning of the public service system of the Russian Federation, established by the Federal Law No. 58-FZ of May 27, 2003 "On the public service system of the Russian Federation". This law provides for a much broader list of principles of public service. Such a state of affairs should hardly be considered satisfactory, since the absence of the entire list of basic constitutional and institutional principles in the sectoral laws hinders creation of effective mechanisms for their implementation in organization of law enforcement services in individual departments. In some cases, constitutional principles generally acquire a peculiar interpretation, which significantly devalues their meaning and content. For instance, the constitutional principle of legality is not disclosed in sectoral laws on the service; it is reduced to implementation of certain provisions, namely, the employee's obligation to "be guided by the legislation of the Russian Federation" and prohibition of an unlimited circle of persons to "interfere in the legitimate activities of an employee, except for persons entitled to it under the federal law".

At the same time, the constitutional meaning of this principle is expressed primarily in "distribution and limitation of power by law in order to ensure rights and freedoms of citizens" [14, p. 11, 12] and protection of citizens from any forms of arbitrariness on the part of the authorities. In this regard, the content of the principle of legality in PES employees' activities should acquire a genuine constitutional meaning, presupposing that an employee is obliged not only to strictly comply with the law, but also demand its compliance from other persons. Moreover, there should be prohibition on the execution of heads' orders and directions that contradict the current Constitution of the Russian Federation and federal legislation.

Priority areas for further betterment of the legislation on service in the penal enforcement system, in addition to the introduction of a detailed system of principles, are the following:

elimination of contradictions in employees' rights;

more thorough regulatory development of administrative procedures related to selection of candidates, service and its termination, as well as appeal of actions and decisions that violate employees' rights; establishment of guarantees for employees' social protection, etc. [11].

\section{PES personnel policy concept}

Every new political or economic task, every fundamental decision should provide for the implementation of appropriate measures in the field of personnel management. This applies to both short-term and long-term activities that require thorough training and advanced training of existing and new personnel [3, p. 82]. Domestic authors discuss a systemic impact that state authorities staffing on the performance of its main functions. For example, A.V. Obolonskii, consistently considering public administration through the influence of human potential on it, notes that the very logic of social development puts the human factor to the fore in the system of managerial relations. Realization of social reserves that lie in the human factor becomes one of the main conditions for accelerating social progress [15, p. 3]. We believe, such a position not only has maintained its relevance in the modern period of reforming public relations, but also is theoretically one of the most important premises in considering issues of improving public administration of the penal enforcement system, including public service in the PES and its staffing.

The fundamentals of state policy in the field of public service in the penal enforcement system and its staffing should be fixed in the relevant political and legal conceptual document - a PES personnel policy concept.

The PES personnel policy concept as a basic administrative and political document is a set of views on the goals, objectives, essence and system of public service and staffing of penitentiary bodies and institutions executing criminal penalties, should determine critical directions of personnel policy in the public administration of the penal enforcement system.

The PES personnel policy is the main means of improving performance and is implemented by forming civil service workforce that have necessary professional competencies, conducting training and education of the personnel in accordance with the goals and objectives of state law enforcement activities in the conditions of Russian society democratization.

The main goal of the PES personnel policy is to form and develop a highly professional, stable, versatile workforce to correspond to modern and forecasted socio-political, economic, criminogenic and other conditions. 
Key tasks of the PES personnel policy are the following:

improving manageability of penitentiary bodies and institutions by enhancing scientific, analytical, logistical and information support of personnel manegement, introduction of advanced automated systems in the practice of human resource departments;

creation of an effective system of information exchange of personnel and educational departments with representatives of security services and other law enforcement agencies;

elaboration of the regulatory legal framework of personnel work in the penal enforcement system and its continuous improvement with regard to the changing situation;

creation of an effective mechanism for rotation, professional development, retraining and advanced training of the PES personnel;

promotion of employee's high psychological resistance to various stressful factors, strengthening of spiritual and moral foundations of the service.

\section{Conclusions}

The theoretical and methodological basis to modernize staffing the penal enforcement system should be formed by the corresponding theoretical doctrine of public service and staffing law enforcement in general and the PES in particular, based on the paradigm of integrative understanding of law and scientific ideas about development of constitutional democracy and administrative constitutionalism in modern Russia.

Modernization of administrative legislation on public service in penitentiary bodies and institutions should also be considered an important direction of improving performance of the law enforcement system. Legislative work in this area should involve implementation of basic constitutional principles of federalism, legality, priority of human rights and freedoms in penal enforcement legislation and practice. Among other institutional principles known to domestic and foreign public law in the field of unity of public service foundations there are the following: openness of public service, stability of service, accessibility of information about service, interaction with public associations and citizens, protection of employees, as well as organizational and legal principles of publicity, priority of professionalism and personal service, prestige and special social status of employees, decent state monetary remuneration, compliance of ranks and ranks of professional service activities of various types.

Staffing the penal enforcement system is the most important subsystem of public administration in the field of execution of criminal penalties. The authorities' activity in this area is conditioned by a variety of political, social, economic, legal and organizational factors that have a multidirectional impact on the state of the penitentiary system. In this regard, stabilization of the situation in the penitentiary system, identification of the most important strategic directions for improving its performance, on the one hand, and neutralization of negative factors affecting the penitentiary system, on the other, are possible only on the basis of a competent systematic personnel policy, implying the use of appropriate forms and methods of working with personnel, their training and upbringing, social protection. The most relevant areas of personnel policy in the PES should be fixed in the PES personnel policy concept for the period up to 2030, approved at the level of the Federal Penitentiary Service of Russia.

\section{REFERENCES}

1. In the format of a round table the Academy discussed prospects for improving work with personnel of the penal enforcement system. Akademiya FSIN Rossii: sait [Academy of the Federal Penitentiary Service of Russia: website]. Available at: https://apu.fsin.gov.ru/news/detail.php?ELEMENTIID=484858 (accessed October 25, 2021). (In Russ.).

2. General'naya Prokuratura Rossiiskoi Federatsii. Portal pravovoi statistiki: ofitsial'nyi sait [The Prosecutor General's Office of the Russian Federation. Portal of legal statistics: official website]. Available at: http://crimestat.ru / (accessed October 25, 2021).

3. Gerber R., Young G. Kadry v sisteme sotsialisticheskogo upravleniya [Staffing in the socialist management system]. Edited by Senin M.V. Translated by Khorokhordin V.A. Moscow: Progress, 1970. 207 p.

4. Gir'ko S.I., Dolgopolov A.A. Penitentsiarnaya prestupnost': sovremennoe sostoyanie i tendentsii [Penitentiary crime: current state and trends]. Nauchnyi portal MVD Rossii=Scientific Portal of the Russia Ministry of the Interior, 2021, no. 1(53), pp. 18-24. (In Russ.). 
5. Head of the FSIN complained about the lack of employees and high loads. RIA Novosti: ofitsial'nyi sait [RIA Novosti: official website]. Available at: https://turbo.ria.ru/20210312/fsin-1600960376.html (accessed November 4, 2021). 6. Zhitkov A.A. Development of criminal legislation in the field of anti-corruption. In: Aktual'nye voprosy naznacheniya $i$ ispolneniya ugolovnykh nakazanii: Sbornik nauchnykh trudov [Topical issues of the appointment and execution of criminal penalties: collection of scientific papers]. Ed. by V.N. Nekrasov. Vologda: Vologodskii institut prava i ekonomiki Federal'noi sluzhby ispolneniya nakazanii, 2017. Pp. 72-77. (In Russ.).

7. Zor'kin V.D. The Constitutional Court at the turn of the fourth decade. Rossiiskaya gazeta=Russian Newspaper, 2021 , no. 247(8598), pp. 1-9. Available at: https://cdnimg.rg.ru/pril/fascicle/4/39/93/43993-1635363078.pdf (accessed October 29, 2021).

8. Klement'ev, A.A. On the category "non-law" in the paradigm of integrative law comprehension. Vestnik Yuzhno-Ural'skogo gosudarstvennogo universiteta. Seriya: Pravo=Bulletin of South Ural State University. Ser. Law, 2019, vol. 19, no. 3, pp. 81-85. (In Russ.).

9. Mel'nikova N.A. Administrative and legal means of preventing and suppressing corruption in the penal system. In: Aktual'nye problemy deyatel'nosti podrazdelenii UIS: sbornik materialov Vserossiiskoi nauchno-prakticheskoi konferentsii, Voronezh, 26 maya 2016 goda [Actual problems of the activities of the PES units: collection of materials of the All-Russian scientific and practical conference, Voronezh, May 26, 2016]. Voronezh: Izdatel'sko-poligraficheskii tsentr "Nauchnaya kniga", 2016. Pp. 346-349. (In Russ.).

10. Mel'nikova N.A. Ratio of the norms of administrative and penal enforcement law in the regulation of the activities of bodies and institutions of the Federal Penitentiary Service of Russia. Rossiiskii sledovatel'=Russian Investigator, 2007, no. 18, pp. 27-29. (In Russ.).

11. Moskalkova stated contradictions in the laws on the rights of police officers. RIA Novosti: ofitsial'nyi sait [RIA Novosti: official website]. Available at: https://ria.ru/20190626/1555929023.html (accessed November 6, 2021).

12. Nagornykh R.V. Administrativno-pravovoe regulirovanie gosudarstvennoi sluzhby Rossiiskoi Federatsii $v$ pravookhranitel'noi sfere: avtoreferat dissertatsii na soiskanie uchenoi stepeni doktora yuridicheskikh nauk [Administrative and legal regulation of public service of the Russian Federation in the law enforcement sphere: Doctor of Sciences (Law) dissertation abstract]. Moscow, 2017. 22 p.

13. Nagornykh R.V. Gosudarstvennaya sluzhba Rossiiskoi Federatsii v pravookhranitel'noi sfere: problemy teorii i praktiki administrativno-pravovogo regulirovaniya: monografiya [Public service of the Russian Federation in the law enforcement sphere: problems of theory and practice of administrative and legal regulation: monograph]. Moscow: Obshchestvo s ogranichennoi otvetstvennost'yu "Nauchno-izdatel'skii tsentr INFRA-M", 2018. 190 p.

14. Nechipas Yu.V., Poberezhnaya I.A. Principle of constitutional legality and its implementation. Trudy Akademii upravleniya MVD Rossii=Proceedings of the Academy of Management of the Ministry of Internal Affairs of Russia', 2016, no. 3(39), pp. 9-12. (In Russ.).

15 15. Obolonskii A.V. Chelovek i gosudarstvennoe upravlenie [Man and public administration]. Ed. by Piskotin M.I. Moscow: Nauka, 1987. 254 p.

16. Oboturova N.S. The problem of human rights in the context of the ideas of humanism and transhumanism. Penitentsiarnaya nauka=Penitentiary Science, 2020, vol. 14, no. 2, pp. 155-161. (In Russ.).

17. Almost 100 criminal cases were initiated against FSIN employees in 2020. RIA Novosti: ofitsial'nyi sait [RIA Novosti: official website]. Available at: https://ria.ru/20201128/fsin-1586762321.html (accessed October 21, 2021). (In Russ.).

18. Alebastrova I.A., et al. Sovremennyi rossiiskii konstitutsionalizm: problemy stanovleniya i perspektivy razvitiya: monografiya [Modern Russian constitutionalism: problems of formation and prospects of development: monograph]. Ed. by Komarova V.V., Sadovnikova G.D. Moscow: Norma : INFRA-M, 2018. 448 p. Available at: https://znanium.com/catalog/ product/949363 (accessed 3, 2021).

19. Stepanenko Yu.V. Law enforcement: the evolution of theoretical views. Aktual'nye problemy administrativnogo prava $i$ protsessa=Actual problems of administrative law and process, 2013, no. 1, p. 8. (In Russ.).

20. Vasil'eva Ya.V., Vedyashkin S.V., Kononov A.M., et al. Sushchnost', formy i metody realizatsii ispolnitel'noi vlasti : uchebnoe posobie dlya magistratury po napravleniyu podgotovki "Yurist v sfere gosudarstvennogo upravleniya" [Essence, forms and methods of implementing executive power: textbook for a master's degree in the field of training "Lawyer in the field of public administration"]. Vologda: Vologodskii institut prava i ekonomiki Federal'noi sluzhby ispolneniya nakazanii, 2019. $163 p$.

21. Klenk T., Reiter R. Post-new public management: reform ideas and their application in the field of social services. International Review of Administrative Sciences, 2019, vol. 85, no. 1, pp. 3-10. Available at: https://journals.sagepub. com/doi/full/10.1177/0020852318810883 (accessed November 8, 2021).

22. Lee S.Z., Our administered constitution: administrative constitutionalism from the founding to the present. Faculty Scholarship at Penn Law, 2019. Available at: https://scholarship.law.upenn.edu/cgi/viewcontent.cgi?article=3086\&contex $\mathrm{t}=$ faculty_scholarship (accessed November 3,2021 )

23. Lewans M. Administrative constitutionalism and the unity of public law. Osgoode Hall Law Journal, 2018, no. 55.2, pp. 515-556. Available at: https://digitalcommons.osgoode.yorku.ca/cgi/viewcontent.cgi?article=3292\&context=ohlj (accessed November 8, 2021)

24. Mazouz B., Rousseau A., Hudon P.A. Strategic management in public administrations: a results-based approach to strategic public management. International Review of Administrative Sciences, vol. 82, no. 4, pp. 621-832. Available at: https://www.cairn-int.info/journal-management-2020-2-page-42.htm (accessed November 8, 2021)

25. Metzger G.E., Administrative Constitutionalism. Texas Law Review, 2013, vol. 91, pp. 1897-1935. Available at: https:// scholarship.law.columbia.edu/cgi/viewcontent.cgi?article=1744\&context=faculty_scholarship (accessed November 3, 2021). 


\section{INFORMATION ABOUT THE AUTHORS}

ROMAN V. NAGORNYKH - Doctor of Sciences (Law), Associate Professor, Honorary Worker of Higher Professional Education of the Russian Federation, Professor of the Department of Administrative Law of Vologda Institute of Law and Economics of the Federal Penitentiary Service of Russia, Vologda, Russian Federation, ORCID: https://orcid.org/00000002-4765-8550, e-mail: nagornikh-vipe@mail.ru

YANA V. VASIL'EVA - Candidate of Sciences (Law), Associate Professor of the Department of Administrative and Financial Law of the North-Western Institute (branch) of the Moscow State Law Academy named after Kutafin O.E., Vologda, Russian Federation, ORCID: https://orcid.org/0000-0001-9434-7563, e-mail: yana.vasileva@list.ru

NATALIYA A. MEL'NIKOVA - Candidate of Sciences (Law), Associate Professor, Associate Professor of the Department of Administrative Law of Vologda Institute of Law and Economics of the Federal Penitentiary Service of Russia, Vologda, Russian Federation, ORCID: https://orcid.org/0000-0002-3697-4769, e-mail: melnatale@mail.ru

Received November 10, 2021 